\title{
COGNITIVE AND LANGUAGE DEFICITS IN VASCULAR DEMENTIA
}

\author{
Slavica Vasilijević ${ }^{1}$, Mile Vuković2, Lana Jerkić3
}

\begin{abstract}
Vascular dementias $(\mathrm{VaD})$ represent a progressive decline in cognitive functions to the extent that it interferes with daily activities performance. Although it is a relatively common form of dementia that occurs in frequency right after Alzheimer's disease (AD) there are far fewer studies that focus on studying cognitive and behavioral changes compared to $A D$. The clinical picture and course of the disease differ between different types.

Due to the heterogeneity of the manifestation of cognitive deficits in $\mathrm{VaD}$, in the literature, these deficits are mostly reported through case studies, mainly in persons with subcortical lesions. Disorders are manifested on the cognitive, motor, behavioral, and functional levels. Vascular dementias are clinically manifested by disorders of language, memory, reasoning, and executive functions. However, visuospatial deficits, attention and praxis deficits, reasoning disturbances, and other disorders can also be manifested. When a stroke occurs at the level of large blood vessels, disorders of language and visuospatial abilities, aphasia, apraxia, memory disorders, and amnesia are mostly manifested. Stroke at the level of small blood vessels manifests disorders of executive functions, attention, planning, more pronounced neuropsychiatric symptoms and other disorders.

The pathophysiology of the symptoms of cognitive impairment in $\mathrm{VaD}$ is still not sufficiently known. There is an opinion that the appearance of language disorders in the form of aphasia also contributes to and complicates the assessment of memory and other cognitive functions. Essential parts of the diagnosis of $\mathrm{VaD}$ are neurological and neuropsychological assessment, while treatment is based on drug therapy, psychosocial support, and speechlanguage therapy.
\end{abstract}

Acta Medica Medianae 2021;60(3):80-89.

Key words: vascular dementias, cognitive deficits, language disorders, neuropsychological assessment, speech-language therapy

\footnotetext{
${ }^{1}$ Health Center Novi Beograd, Belgrade, Serbia

${ }^{2}$ University of Belgrade, Faculty of Special Education and Rehabilitation, Belgrade, Serbia

${ }^{3}$ University of Belgrade, Faculty of Special Education and

Rehabilitation, Ph.D. student, Belgrade, Serbia
}

Contact: Slavica Vasilijević

43/3a Radnička Str., 11000 Belgrade, Serbia

E-mail: slavica.vasilijevic10@gmail.com

\section{Introduction}

Vascular dementia (VaD) is a term used to describe impairment of cognitive functions due to cerebrovascular disorders, such as multiple cortical/ subcortical infarcts, strategic single infarcts, noninfarct white matter lesions, hemorrhagia, and hypoperfusion (1). The clinical picture of $\mathrm{VaD}$ can develop abruptly or gradually, three months after or independently of stroke (2). The location and size of the infarct, the degree of related neurological damage, the presence of a previous cognitive deficit, and other cerebral pathologies may influence the development of dementia following a stroke. The influence of genetic factors is still not sufficiently known (3). Although cognitive and language deficits primarily manifest $\mathrm{VaD}$, the literature is relatively scarce with data in this area. This paper focuses on presenting and analyzing previous empirical data on language and cognitive functions in people with $\mathrm{VaD}$.

\section{The aim}

Our goal was to systematically present data on language and cognitive deficits in different types of vascular dementia. We also attempted to present the basic guidelines of the diagnostic procedure and non-pharmacological form of $\mathrm{VaD}$ therapy.

\section{Method}

The following electronic databases and search engines were used to search the relevant literature: 
Serbian Library Consortium for Coordinated Acquisition (KoBSON), Google Scholar, PubMed, and Science Direct. The following search keywords were: vascular dementia, speech and language disorders in vascular dementia, cognitive deficits in vascular dementia, large blood vessel disease and small blood vessel disease, multi-infarct dementia, Binswanger's disease, CADASIL.

\section{Definition and epidemiology of vascular}

Vascular dementia is manifested by a decline in cognitive abilities that occurs due to vascular disorders and is sufficiently pronounced to interfere with the affected person's daily living (4). Vascular dementia represents a multiple cognitive disorder that involves two or more cognitive functions (memory, language, praxis, gnosis, executive functions). The disorder may also manifest in the areas of emotions and/or personality (5). Vascular dementia is a relatively common form of dementia and is right after Alzheimer's disease (AD) in terms of frequency. It is estimated that $\mathrm{VaD}$ constitutes about $20 \%$ of all cases of dementia $(6,7,8)$.

\section{Risk factors and types of VaD}

By considering the relationship between risk factors and the occurrence of dementia, it is assumed that any cause that disrupts regular blood circulation could have a significant role in the pathogenesis of $\mathrm{VaD}$ (9). Risk factors for $\mathrm{VaD}$ can be divided into four groups: demographic (age, male, lower education), genetic (Binswanger's disease), atherosclerotic (such as diabetes, smoking, hypertension, and more), and stroke-related factors (volume of brain lesion, strategic infarct, and other causes) $(5,10,11)$. Age is considered to be the most significant risk factor, as evidenced by empirical data according to which with increasing age, the incidence doubles every 5.3 years (12).

According to the basic mechanism of occurrence, $\mathrm{VaD}$ is classified into ischemic, hemorrhagic, and hypoxic (13). There are four primary clinical varieties of $\mathrm{VaD}$, namely:

a) multi-infarct dementia;

b) dementia after a strategically placed stroke;

c) subcortical dementia (Binswanger's disease) and

d) cerebral autosomal dominant arteriopathy with subcortical infarcts and leukoencephalopathy (CADASIL) $(5,9,14)$.

Different combinations are possible, but $\mathrm{VaD}$ most often occurs in association with $A D$, and then it is called mixed dementia (15). More detailed classifications are possible where vascular dementia is divided into multi-infarct dementia, lacunar dementia, Binswanger's disease, mixed dementia, subcortical dementia with genetically determined arteriolopathies, infectious vasculitis, autoimmune vasculitis, post-hemorrhagic hydrocephalus and others (13).

\section{Cognitive deficits}

\section{Cognitive deficits in VaD}

Although $\mathrm{VaD}$ is in second place in terms of frequency, considerably less studies focus on $\mathrm{VaD}$ compared to $A D$ as the most common type of dementia. Literature's data show that research is more focused on studying neurological factors than on the disorder's cognitive and behavioral aspects (16). Due to the heterogeneity of symptom manifestations in $\mathrm{VaD}$, cognitive functioning profiles in individuals with $\mathrm{VaD}$ have been most commonly presented through case studies, predominantly in patients with subcortical lesions (17).

The clinical picture of $\mathrm{VaD}$ dominates by cognitive, motor, behavioral and functional deficits. In multi-infarct $\mathrm{VaD}$ or in strategically placed stroke, cognitive deterioration occurs acutely or gradually up to three months after or independently of stroke (18). A whole range of symptoms of cognitive impairment has been described, such as memory loss, emotional lability, transcortical motor aphasia, apraxia, fluent aphasia, anomia, alexia with/without agraphia, disturbances in abstract reasoning, impaired judgment, impulse control, personality changes disturbances, prosody damage, visual agnosia, and visual hallucinations. A specific type of symptoms' appearance depends on the infarct lesion's location and size (19). Memory deficits do not have to manifest at the very beginning of the disease. However, usually there can be noticed the lateralization of disturbances in the domain of this ability, i.e., the discrepancy between verbal (role of the left hemisphere) and visual memory (role of the right hemisphere) (18). Clinical pictures and course differ between individual types.

The manifestation of cognitive deficits depends on whether the infarcts are in small or large blood vessels. In infarcts in large blood vessels, disorders of linguistic and visuospatial functions are more pronounced $(20,21)$; cortical syndromes such as aphasia, apraxia, and amnesia also manifest (22), as well as memory disorders (21). In infarcts in small blood vessels, a disorder of executive functions occurs and also deficits of attention, planning, and monitoring in memory tasks $(21,22)$. Empirical data show that apathy, motor disorders, and hallucinations are pronounced more severely in small blood vessel infarcts when it comes to neuropsychiatric symptoms. Agitation/aggression and euphoria are more reflected in large blood vessels (23).

People with VaD seem confused even when solving simple tasks, what is caused by disproportionate impairment of executive functions and attention (24). Disturbances also manifest during planning and sequencing and when solving unstructured tasks (25). Empirical data also testify about deficits in information processing speed, deficits in construction tasks (26), constructive praxis, and deficits in temporal and spatial orientation (27). 
Some studies highlight that symptoms of depression and anxiety are more pronounced in people with $\mathrm{VaD}$ than in people with $\mathrm{AD}(28,29)$. Interestingly, the research results on the Theory of mind in people with $\mathrm{VaD}$ did not show deficits in this domain and in the domain of emotion recognition (30).

\section{Cognitive deficits in multi-infarct dementia (MID)}

Multi-infarct dementia (MID), previously considered the only type of $\mathrm{VaD}$, is characterized by multiple lacunar and microinfarcts as well as small and large infarcts in the cortex and subcortical structures (11). In this dementia, impaired executive functioning is observed, and mild deficits of episodic memory, affective disorders, and gait disorders (14, 31). Vascular dementia, which occurs due to multiple infarcts in the cerebral cortex, is manifested by a sudden disturbance of cognitive functions, the appearance of aphasia, and lateralized deficits of sensibility and motor skills (5). In these individuals, a combination of impaired cortical functions is observed: memory, attention, praxis, and language, accompanied by neurological deficits, emotional flattening, and loss of social skills $(5,8,32)$. It is characteristic that with each repeated stroke, the patient's condition is getting worse, after which there is an improvement in cognitive abilities, partially or completely (33).

Cognitive deficit in dementia after a strategically placed stroke

The manifestation of the clinical picture of the disorder after a stroke in a particular brain area depends on the localization of the affected structures, i.e., on the affected function for which those areas are responsible. The occurrence of a stroke in the thalamus can cause a severe memory disorder, depending on the affected nuclei and their connections. Memory deficits mainly attribute to lesions of the anterior nuclei (medial and lateral) and medial dorsal nuclei associated with the hippocampus and prefrontal regions (34). Disorders in verbal fluency, set-shifting, sequential reasoning, and motor planning are also observed (35). If an angular gyrus is affected by a stroke, fluent aphasia, alexia with agraphia, Gerstmann's syndrome, or spatial disorientation may occur $(35,36)$. Anterior cerebral artery infarct results in abulia, dynamic /transcortical motor aphasia, memory impairment, and dyspraxia. The middle cerebral artery's affectation on the right side manifests the clinical picture of confusion or psychosis. In contrast, the posterior cerebral artery gives symptoms of visual disturbances, confusion, and hallucinations $(8,32)$.

\section{Cognitive deficits in subcortical dementia (Binswanger's disease)}

Subcortical dementia occurs in small blood vessel infarcts. This type of dementia is also described in the literature as Binswanger's disease or subcortical arteriosclerotic encephalopathy $(37,38)$. Subcortical dementia is considered to be the most common type of disorder caused by vascular causes (39). The medical history of the disease also reveals previous minor strokes and transient ischemic attacks (40). The first symptoms usually appear in the fifth and sixth decades of life, and the disease lasts between five and ten years (33). On the cognitive and behavioral level, there are signs of cognitive decline and dysexecutive syndrome (disturbances in attention control, deficits of working and short-term memory, impulse control, and in the final stage of the disease abulia appears), as well as disorders in information processing speed $(40,41$, 42). It is characteristic that memory loss occurs to a mild degree, while executive functions' deficit occurs relatively early (43). In subcortical $\mathrm{VaD}$, ideomotor apraxia of limbs may also occur (44). Disturbances with the gestures use consequently affect people's communication with people from the environment (9).

Cognitive deficits in cerebral autosomal dominant arteriopathy with subcortical infarcts and leukoencephalopathy (CADASIL)

Cerebral autosomal dominant arteriopathy with subcortical infarct and leukoencephalopathy (CADASIL) is the most common inherited cause of stroke and dementia in adulthood. It occurs as a consequence of pathogenic mutations in the NOTCH3 gene (45). It is considered that the disease is mostly inherited autosomal dominantly and is manifested by a wide range of symptoms that differ even within the same family (46). The clinical picture is dominated by signs of subcortical dementia, which usually begins around the age of 45 . The duration of the disease is variable and lasts between 10 and 40 years (47). In CADASIL, the most reflected are mood disorders and apathy, migraine with aura, executive function disorder, and semantic memory disorders. Cortical syndromes such as agnosia, aphasia, and apraxia are rare $(45,47)$.

\section{Language deficits in VaD}

A literature review suggests that the number of studies examining language skills in patients with $\mathrm{VaD}$ is very modest. Some authors state that a possible reason for this is excluding patients with aphasia from the sample due to neuropsychological assessment limitations (48). Previously, language disorders in dementia were usually attributed to the deterioration of stored knowledge. At the same time, aphasia, which occurs due to stroke, is typically assumed to represent modally specific impairments of access to otherwise intact conceptual knowledge. It has been observed that patients with different forms of aphasia (such as Broka's, transcortical sensory, or optic aphasia) may suffer impairment of nonverbal concepts, which is why some authors state that aphasia and dementia are not entirely separated entities (49).

Some authors point out that the primary language functions in $\mathrm{VaD}$ remain relatively spared but that the motor aspects of speech are affected (25). Speech-language deficits in people with VaD are manifested by phonemic paraphasia, disorders 
in the comprehension and production of syntax, anomia, and disorders of lexical recall, as well as dysprosody $(9,49)$. These patients often manifest dysarthria associated with language deficits (50), unintelligible speech, and produce less complex sentences $(49,51)$. Also, difficulties in word-finding, naming objects, and comprehension of words have been described (52). Comparing the results with the control group, which consisted of subjects without data on neurological impairment, on the Boston Naming Test (BNT), Lukatela and colleagues (53) observed that people with $\mathrm{VaD}$ manifested more semantic and visuoperceptive deficits when naming compared to the control group. In contrast, patients with Alzheimer's disease (AD) reflect more deficits than both groups of subjects. Other authors have also found differences in naming abilities in the two most common types of dementia. One study reports that both subgroups of subjects produced paraphasia and visual errors during confrontational naming. In contrast, circumlocution (producing an unnecessarily large number of words during naming) was more pronounced in the subgroup of subjects with AD (54). Desmond (25) states that nomination's disorders can blur the accurate picture of the state of verbal memory in these patients, i.e., that the results on tests of verbal memory can be significantly worse due to disorders of the nomination.

Vuković and colleagues (55) reported that language disorders were present in all patients on a sample of 10 patients diagnosed with VaD. Language disorders were found to be manifested by the type of anomic, transcortical sensory, and transcortical motor aphasia. In some patients, the language deficit did not correspond to the clinical picture of any known aphasic syndrome. In addition to language disorders, patients showed deficits in executive functions and a decrease in memory ability.

Vuorinen et al. (56), using a standardized Boston Diagnostic Aphasia Examination Test (BDAE) as well as unstructured language tasks ("Cooking theft" from the same battery of tests and while describing objects), concluded that patients with $\mathrm{VaD}$ manifested language disorders similar to those seen in $A D$ diseases. They noticed disturbances in comprehension (especially complex ideational material), picture naming, and semantic expression in discourse. However, repetition and reading of single words, reading sentences aloud, and fluency was not affected (56). Such findings suggest that the network's integrity responsible for the semantic aspect of language may be affected even in the early stages of dementia (5).

Tomić and colleagues (57) described a 53year-old patient with $\mathrm{VaD}$ with reduced fluency in spontaneous speech, dysarthria, impaired rhythm and speech rate, hypotonic articulation, and mild dysprosodia and hypophonia. They also observed disorders of repetition, which they linked to shortterm memory deficits. The patient also had visuoconstructive and visuoperceptive type of errors when writing (57).
Wang and colleagues (58) reported a significantly higher frequency of mirror writing in individuals with $\mathrm{VaD}$ than in the control group. The authors suggest that such an assessment may indirectly indicate the severity of dementia since mirror writing is also a sign of changes in the brain in older people. In multi-infarct dementia, reading and counting disorders, i.e., dyslexia and dyscalculia, can sometimes be observed (4).

Examining language disorders in bilingual persons did not confirm that knowledge of several languages delays the onset of dementia in old age. The authors suggest that delaying the onset of dementia is associated with the frequency of use of the second language in old age (59). Inevitably, speech and language impairments in people with dementia affect communication with other people (52).

\section{Differential diagnosis from Alzheimer's Disease (AD)}

Since the onset of $\mathrm{VaD}$ may present a range of signs of cognitive impairment, some of which (memory and language disorders, for example) are characteristic of Alzheimer's dementia, it is important to note the differences between the profiles of cognitive impairment in these two clinical entities. Clinical data show that patients with $A D$ are less successful on all memory tests than patients with VaD. It is also stated that the sudden onset of cognitive deterioration and frequent disease fluctuations differentiate $\mathrm{VaD}$ from $A D$ (5). It is showed that patients with $A D$ have more difficulty when finding words and have more intrusions. On the other hand, they have better verbal fluency, motor functioning, executive functions, and attention than patients with $\operatorname{VaD}(60)$.

Language disorders in people with $A D$ are a manifestation of a degenerative process, while in multi-infarct dementia, they resemble aphasic syndromes caused by a large infarct (6). Patients with $\mathrm{VaD}$ are thought to have relatively spared long-term memory than persons with $A D$ and manifest more pronounced deficits of executive functions than patients with $A D$ (48). Depression, psychomotor retardation, and social avoidance are more common in $\mathrm{VaD}(5)$. Table 1 shows some of the symptoms that may serve in the differential diagnosis of these two disorders.

Matthias and Burke (62), in their metaanalysis, reported that the most reliable tests for differentiating these two types of dementia were the Emotion Recognition Test (63); delayed memory recall from the Wechsler Memory Rating Scale (64), The Adult Memory and Information Processing Battery (AMIPB) (65) and The Babcock Story Recall Test $(66,62)$.

Genetic studies suggest that the pathogenesis of $A D$ may involve the down-regulation of genes involved in cholinergic transmission. At the same time, vascular dementia may be more closely associated with the down-regulation of cortisol metabolism and secretion (67). 
Table 1. Comparison of the symptoms in $A D$ and $\operatorname{VaD}(14,61)$

\begin{tabular}{||c|c|c||}
\cline { 2 - 3 } \multicolumn{1}{c|}{} & VASCULAR DEMENTIA & ALZHEIMER'S DISEASE \\
\hline $\begin{array}{c}\text { The onset of the } \\
\text { disease }\end{array}$ & Sudden/gradual & Constant insidious decline \\
\hline Disease progression & Slow and gradual progression \\
\hline $\begin{array}{c}\text { Neurological } \\
\text { findings }\end{array}$ & Proven focal lesions & Subtle or absent \\
\hline \begin{tabular}{c} 
Memory disorders \\
\cline { 2 - 3 } Executive functions \\
disorders
\end{tabular} & $\begin{array}{c}\text { Meficits are early manifested and they } \\
\text { are severe }\end{array}$ & $\begin{array}{c}\text { Deficits manifest early and they are more } \\
\text { severe, especially for recent events }\end{array}$ \\
\hline $\begin{array}{c}\text { Gait disturbances } \\
\text { Speech-language } \\
\text { disorders }\end{array}$ & $\begin{array}{c}\text { Disorders manifest early; loss of } \\
\text { bladder/bowel control }\end{array}$ & Normal gait \\
\hline Wisual impairment & Vision disturbances in some cases & $\begin{array}{c}\text { The manifestation of language disorders in } \\
\text { oral speech, writing, and vocabulary }\end{array}$ \\
\hline
\end{tabular}

\section{Neuropsychological assessment and diagnosis of VaD}

The diagnosis of $\mathrm{VaD}$ is made based on anamnesis, neurological examination, neuropsychological assessment, and assessment of the ability to perform daily activities, as well as the application of neuroimaging methods (magnetic resonance imaging - MR, functional magnetic resonance imaging fMRI or computed tomography - CT) $(5,12,13)$.

The most well-known criteria for diagnosing probable $\mathrm{VaD}$ are the NINDS-AIREN criteria (National Institute of Neurological Disorders and Stroke/ Association Internationale pour la Recherche et I'Enseignement en Neurosciences) (68), International Statistical Classification of Diseases, $10^{\text {th }}$ Revision (ICD-10) (69), Diagnostic and Statistical Manual of Mental Disorders, Fourth Edition (DSM-IV) (70), State of California Alzheimer's Disease Diagnostic and Treatment Centers (ADDTC) (71) and the Hachinski Ischemic Scale (HIS) (72).

Tal and colleagues (11) stand out that VaD occurs due to vascular, neurodegenerative, and other lesions, although the diagnosis is made only concerning the vascular etiology. Other authors state that the diagnosis of "pure" VaD should be made if there are lesions that are not characteristic of $A B$ and are not typical for the appropriate age and other accompanying pathologies. Ischemic or vascular lesions of the brain of smaller volume, especially in functionally important ("strategic") parts of the brain or neural loops, can further exacerbate existing neuropsychological disorders in the old brain and $A B(73)$.

In neuropsychological assessment, cognitive abilities tests, batteries of tests for the evaluation of language abilities, and specific tests that assess individual language functions are used (74). Standardized aphasia test batteries such as the Boston Diagnostic Aphasia Examination (BDAE) (75) and the Western Aphasia Battery (WAB) (76), Boston Naming Test (BNT) (77), Sentence production test, cohesion and discourse coherence, phonemic and semantic fluency test (5), Arizona Battery for Communication Disorders of Dementia (ABCD) (78) as well as a Token test can be used to assess comprehension (79).

\section{Non-pharmacological treatment and the} role of speech-language therapy

It is estimated that about $90 \%$ of strokes and $35 \%$ of dementias can be prevented. Since stroke increases the chances of developing dementia, it is considered that stroke prevention can inhibit the occurrence of more than a third of dementias (80), which primarily refers to $\mathrm{VaD}$, whose primary cause is cerebrovascular. VaD treatment should be based on timely diagnosis, neuropsychological assessment, and treatment of comorbidities. The patient and his family members should be informed about the nature of the disease, emphasizing the importance of maintaining the person's independence for as long as possible. It is necessary to ensure the control of vascular risk factors, recognize and adequately treat cognitive deficits, and create adequate psychosocial and other conditions that will improve the quality of life of $\mathrm{VaD}$ and their caregivers (12). Potential protective factors such as antihypertensive therapy, alcohol avoidance, higher education, physical activity, Mediterranean diet, and an active lifestyle have also been singled out as important in preventing the occurrence of dementia $(16,81,82)$.

The psychosocial approach to rehabilitating people with dementia is widespread, but only some treatment forms represent evidence-based interventions. Patel and colleagues (83) have singled out several forms of treatment that include a psychosocial approach, which seems to be justifiably used in people with dementia and/or their caregivers. Those are music therapy, aromatherapy, post-diagnostic support and supporting caregivers, life story work, and animal-assisted therapy. Some authors concluded that various psychotherapeutic interventions have different effects on neuropsychiatric conditions that accompany $\mathrm{VaD}$. The psychotherapeutic 
approach has better results when treating irritability, anxiety, or depression than emotional incontinence and apathy (84).

Cognitive intervention refers to the rehabilitation of cognitive impairments and to a wide range of interventions for people with dementia (such as improving daily living and its activities, speech and communication disorders, self-care, and more). All of these techniques include re-learning individual abilities or new learning, as well as a combination of both approaches (85). Some authors point out that cognitive stimulation, which is used in people with mild to moderate dementia, can improve cognitive abilities, improving the quality of life and communication in people with dementia (86). Based on monitoring the recovery of the 76-year-old patient, Soedirman and Laksmidewi (87) noticed the positive effects of cognitive stimulation on cognitive functioning and daily living activities. However, Clare and colleagues (88) review did not show significant effects of cognitive training in improving abilities in patients with milder forms of Alzheimer's disease and $\mathrm{VaD}$ due to methodological limitations of the studies included. Also, cognitive training efficacy has not been proven in another review ten years later (89).

Of the non-pharmacological forms of treatment, an important aspect is also speech-language therapy since people with $\mathrm{VaD}$ often show impairment of speech and language functions. The aim of speech-language therapy in people with dementia is to preserve communication skills, delay the progression of dementia, and compensate for the loss of language skills (90). Treatment of communication deficits can be carried out using one of the following approaches: direct speech-language therapy, training of interlocutors in communication, or the usage of augmentative and alternative technology (9). Applying specific treatment methods makes it possible to slow down the deterioration of speech and language abilities (90). In addition, some authors point out that tasks aimed to improve nomination in these patients contribute to the rehabilitation of vocabulary and positively affect disease prognosis despite the disease's degenerative nature (91).

It is believed that assistive technology in people with dementia and language disorders has specific benefits. In this way, their spoken and written communication can be significantly enhanced. Using assistive technology, people with dementia can improve or use it as an alternative to spoken or written communication. For example, assistive technology (such as speech-generating devices) improves patients' verbal communication, and memory aids help them remember names (92). The role of speech therapists is essential in providing interventions in treating people with dementia to maintain the ability to communicate and provide support to family members (93).

\section{Conclusion}

Vascular dementia (VaD) is relatively common in people with dementia, and in frequency, they are immediately after Alzheimer's disease (AB). VaD is a group of disorders caused by vascular factors. There are several types of $\mathrm{VaD}$ : multi-infarct dementia, dementia due to strategically placed infarct, Binswanger's disease, and CADASIL, which is hereditary dementia. A literature review shows that a variable clinical picture is described in vascular dementia and that the profile of cognitive impairment often depends on the location of the infarct, the extent of the brain lesion, the existence of a previous cognitive impairment, and other factors.

Concerning the brain area affected by infarct, which is associated with dementia, the specifics of cognitive disorders have been shown. Disorders of executive functions are mainly manifested in persons with infarcts of small blood vessels, while language and visuospatial deficits are more pronounced in damage to large blood vessels. Large infarcts in the carotid system's terminal branches cause disorders that manifest by different types of cortical syndromes (such as aphasia, amnesia, apraxia, etc.). Due to the heterogeneity of the manifestation of disorders in $\mathrm{VaD}$, the literature is scarce with data on the specifics of cognitive and language deficits.

The diagnosis of dementia is based on neurological examination, neuroimaging methods, and neuropsychological testing. In the treatment of $\mathrm{VaD}$, besides drug therapy, non-pharmacological forms of treatment are also used. Interventions are mostly based on a psychosocial approach. Given the prevalence of language disorders, speech-language therapy is an essential aspect of treating patients with vascular dementia. It is believed that speech and language therapy slows down dementia and improves the patient's and his family members' quality of life.

\section{Acknowledgements}

The paper is a result of research on the project "Evaluation of treatment of acquired speech and language disorders" (ON 179068), funded by the Ministry of Education, Science and Technological Development of the Republic of Serbia. 


\section{References}

1. Mijajlović M, Pavlović A, Brainin M, Heiss W, Quinn T, Ihle-Hansen $\mathrm{H}$ et al. Post-stroke dementia - a comprehensive review. BMC Med 2017;15(1):1-12. [CrossRef] [PubMed]

2. Pavlovic $D$, Pavlovic A. New findings on dementias. Engrami 2002;24(3-4):9-28.

3. Kalaria $R$, Akinyemi $R$, Ihara M. Stroke injury, cognitive impairment and vascular dementia. Biochim Biophys Acta (BBA) - Molecular Basis of Disease 2016; 1862(5):915-25. [CrossRef] [PubMed]

4. Pavlovic D. Demencije: dijagnoza, terapija i nega. Beograd: Orion Art;2012.

5. Vuković M. Neurodegenerativni poremećaji govora i jezika. Beograd: Univerzitet u Beogradu, Fakultet za specijalnu edukaciju i rehabilitaciju; 2019.

6. Kontiola $\mathrm{P}$, Laaksonen $\mathrm{R}$, Sulkava R, Erkinjuntti $\mathrm{T}$. Pattern of language impairment is different in Alzheimer's disease and multi-infarct dementia. Brain and Lang 1990;38(3):364-83. [CrossRef] [PubMed]

7. Kalaria R, Maestre G, Arizaga R, Friedland R, Galasko $D$, Hall $K$ et al. Alzheimer's disease and vascular dementia in developing countries: prevalence, management, and risk factors. Lancet Neur 2008;7(9): 812-26. [CrossRef] [PubMed]

8. Gorelick P, Scuteri A, Black S, DeCarli C, Greenberg S, Iadecola $C$ et al. Vascular Contributions to Cognitive Impairment and Dementia. Stroke 2011;42(9):2672713. [CrossRef] [PubMed]

9. Cummings L. Language in dementia. Cambridge: Cambridge University Press;2020.

10. Gorelick P. Risk factors for Vascular Dementia and Alzheimer Disease. Stroke 2004;35:2620-22. [CrossRef]

11. Thal D, Grinberg L, Attems J. Vascular dementia: Different forms of vessel disorders contribute to the development of dementia in the elderly brain. Exp Gerontol 2012;47(11):816-24. [CrossRef] [PubMed]

12. O'Brien J, Thomas A. Vascular dementia. The Lancet 2015;386(10004):1698-706. [CrossRef] PubMed]

13. Pavlovic D, Pavlovic A. Demencije - neuropsihijatrijski simptomi (bihevioralni i psiholoski simptomi demencije). Beograd: Orion Art;2014.

14. Román G. Vascular Dementia: Distinguishing Characteristics, Treatment, and Prevention. J Am Geriatr Soc 2003;51(5s2):S296-S304. [CrossRef] [PubMed]

15. Langa K, Foster N, Larson E. Mixed Dementia: emerging concepts and therapeutic implications. JAMA 2004; 292(23):901-2908. [CrossRef] [PubMed]

16. Watari K, Gatz M. Dementia: A cross-cultural perspective on risk Factors. Generations: Journal of the American Society on Aging 2020;26(1):32-38.

17. Desmond D, Erkinjuntti T, Sano M, Cummings J, Bowler J, Pasquier F et al. The Cognitive Syndrome of Vascular Dementia. Alzheimer Disease \& Associated Disorders. 1999;13(Supplement):S21-9. [CrossRef]

18. Pavlovic D, Pavlovic A. Vise kortikalne funkcije: neuropsihologija i neurologija ponasanja. Beograd: Orion Art;2016.

19. Payne J. Adult neurogenic language disorders: Assessment and treatment. A comprehensive ethnobiological approach. $2^{\text {nd }}$ ed. San Diego: Plural Publishing;2014.

20. Ying $H$, Jianping $C$, Jianqing $Y$, Shanquan Z. Cognitive variations among vascular dementia subtypes caused by small-, large-, or mixed-vessel disease. Arch Med Sci 2016;4:747-53. [CrossRef] [PubMed]
21. Sengupta P, Ganguly J, Pal S, Ghosal M. Pattern of cognitive deficits in vascular dementia. Indian $\mathrm{J}$ Med Res 2019;149(4):503-7. [CrossRef] [PubMed]

22. Iemolo F, Duro G, Rizzo C, Castiglia L, Hachinski V, Caruso C. Pathophysiology of vascular dementia. Immun Ageing 2009;6(1):13. [CrossRef]

23. Staekenborg S, Su T, van Straaten E, Lane R, Scheltens $\mathrm{P}$, Barkhof $\mathrm{F}$ et al. Behavioural and psychological symptoms in vascular dementia; differences between small- and large-vessel disease. J Neurol Neurosurg Psychiatry 2009;81(5):547-51.

[CrossRef] [PubMed]

24. Roman G. Controversies in vascular dementia. Seminars in Cerebrovascular Diseases and Stroke 2004; 4(2):117-20. [CrossRef]

25. Desmond D. The neuropsychology of vascular cognitive impairment: is there a specific cognitive deficit? J Neurol Sci 2004;226 (1-2):3-7. [CrossRef] [PubMed]

26. Kertesz A, Clydesdale S. Neuropsychological Deficits in Vascular Dementia vs Alzheimer's Disease. Arch Neurol 1994;51(12):1226-31. [CrossRef] [PubMed]

27. Lumi D, Grabova S, Quka A, Djamandi P, Kruja J. Neuropsychological impairment in vascular dementia. J Neurol Sci 2019;405:30. [CrossRef]

28. Kim J, Lyons D, Shin I, Yoon J. Differences in the behavioral and psychological symptoms between Alzheimer's disease and vascular dementia: are the different pharmacologic treatment strategies justifiable? Hum Psychopharmacol 2003;18(3):215-20. [CrossRef] [PubMed]

29. Tiel C, Sudo F, Alves G, Ericeira-Valente L, Moreira D, Laks J et al. Neuropsychiatric symptoms in Vascular Cognitive Impairment: A systematic review. Dement Neuropsychol 2015;9(3):230-6. [CrossRef] [PubMed]

30. Shany-Ur T, Poorzand P, Grossman S, Growdon M, Jang J, Ketelle R et al. Comprehension of insincere communication in neurodegenerative disease: Lies, sarcasm, and theory of mind. Cortex 2012;48(10): 1329-41. [CrossRef] [PubMed]

31. McKay E, Counts S. Multi-Infarct Dementia: A Historical Perspective. Dement Geriatr Cogn Disord 2017; 7(1):160-71. [CrossRef] [PubMed]

32. Pavlovic A, Pavlovic D, Aleksic V, Sternic N. Vascular dementia: Facts and controversies. Srp Arh Celok Lek 2013;141(3-4):247-55. [CrossRef] [PubMed]

33. Strub R. Vascular Dementia. Ochsner J 2003;5(1): 40-3. [CrossRef]

34. Lanna M, Madeira D, Alves G, Alves C, Valente L, Laks J et al. Vascular dementia by thalamic strategic infarct. Arq Neuropsiquiatr 2008;66(2b):412-14. [CrossRef]

35. McPherson S, Cummings J. Neuropsychological Aspects of Vascular Dementia. Brain Cogn 1996;31(2): 269-82. [CrossRef] [PubMed]

36. MacDonald S, Grand JH, Caspar SW. Clinical features and multidisciplinary approaches to dementia care. J Multidiscip Healthc 2011;4:125-47. [CrossRef] [PubMed]

37. Burger P, Burch J, Kunze U. Subcortical arteriosclerotic encephalopathy (Binswanger's disease). A vascular etiology of dementia. Stroke 1976;7(6):626-31. [CrossRef] [PubMed]

38. Ramos-Estebanez C, Moral-Arce I, Gonzalez-Mandly A, Dhagubatti V, Gonzalez-Macias J, Munoz R et al. Vascular cognitive impairment in small vessel disease: clinical and neuropsychological features of lacunar 
state and Binswanger's disease. Age Ageing 2011; 40(2):175-80. [CrossRef] [PubMed]

39. Rosenberg G. Binswanger's disease: biomarkers in the inflammatory form of vascular cognitive impairment and dementia. J Neurochem 2017;144(5):634-43. [CrossRef] [PubMed]

40. Huisa B, Rosenberg G. Binswanger's disease: toward a diagnosis agreement and therapeutic approach. Expert Rev Neurother 2014;14(10):1203-13. [CrossRef] [PubMed]

41. Văcăraș V, Cordoș AM, Rahovan I, Frunze S, Mureșanu DF. Binswanger's disease: Case presentation and differential diagnosis. Clin Case Rep 2020; 00:1-8. [CrossRef] [PubMed]

42. O'Sullivan M. Brief cognitive assessment for patients with cerebral small vessel disease. J Neurol Neurosurg Psychiatry 2005;76(8):1140-45. [CrossRef] [PubMed]

43. Trkanjec Z. Vaskularna demencija. Medix: specijalizirani medicinski dvomjesečnik 2014;20(111):197-203.

44. Ozkan S, Adapinar DO, Elmaci NT, Arslantas D. Apraxia for differentiating Alzheimer's disease from subcortical vascular dementia and mild cognitive impairment. Neuropsychiatr Dis Treat 2013;9:947-51. [CrossRef] [PubMed]

45. Chabriat $H$, Joutel $A$, Dichgans $M$, Tournier-Lasserve $E$, Bousser M. CADASIL. The Lancet Neurology 2009; 8(7):643-53. [CrossRef] [PubMed]

46. Wang M, Peng D, Cai X, Li S. CADASIL. Handbook of Clinical Neurology 2018;148:733-43. [CrossRef] [PubMed]

47. Hervé D, Chabriat H. CADASIL. Journal of Geriatric Psychiatry and Neurology 2010;23(4):269-76. [CrossRef] [PubMed]

48. Looi J, Sachdev P. Differentiation of vascular dementia from AD on neuropsychological tests. Neurology 1999; 53(4):670-670. [CrossRef] [PubMed]

49. Reilly J, Rodriguez A, Lamy M, Neils-Strunjas J. Cognition, language, and clinical pathological features of non-Alzheimer's dementias: An overview. J Commun Disord 2010;43(5):438-52. [CrossRef] [PubMed]

50. Ross G, Cummings J, Benson D. Speech and language alterations in dementia syndromes: Characteristics and treatment. Aphasiology 1990;4(4):339-52. [CrossRef]

51. Klimova B, Semradova I. Cognitive decline in dementia with special focus on language impairments. In: Bekirogullari Z, Minas MY, Thambusamy RX, editors. CPSYC 2016: $4^{\text {th }}$ International Congress on Clinical and Counselling Psychology; European Proceedings of Social and Behavioural Sciences. 2016 May 10-12; Cyprus: Nicosia;2016; p.86-90.

52. Klimova B, Kuca K. Speech and language impairments in dementia. J Appl Biomed 2016;14(2):97-103. [CrossRef]

53. Lukatela $K$, Malloy $P$, Jenkins M, Cohen R. The naming deficit in early Alzheimer's and vascular dementia. Neuropsychology 1998;12(4):565-72. [CrossRef] [PubMed]

54. Freitas M, Porto C, Oliveira M, Brucki S, Mansur L, Nitrini $R$ et al. Linguistic abilities in major vascular cognitive impairment: a comparative study with Alzheimer's disease. Acta Neurol Belg 2018;118(3): 465-73. [CrossRef] [PubMed]

55. Vuković M, Jovanović-Simić N, Kulić M. Komparativna analiza neuropsihološkog nalaza kod Alchajmerove i vaskulne demencije. Foča: Medicinski fakultet, Foča; 2014. p. 123-38.

56. Vuorinen E, Laine M, Rinne J. Common Pattern of Language Impairment in Vascular Dementia and in Alzheimer Disease. Alzheimer Dis Assoc Disord 2000; 14(2):81-6. [CrossRef] [PubMed]
57. Tomić G, Stojanović M, Pavlović A, Stanković $P$, Zidverc-Trajković J, Pavlović D et al. Speech and language disorders secondary to diffuse subcortical vascular lesions: Neurolinguistic and acoustic analysis. A case report. J Neurol Sci 2009;283(1-2):163-69. [CrossRef] [PubMed]

58. Wang $X$. Mirror writing in elderly patients with Alzheimer disease and vascular dementia. Neural Regen Res 2007;2(4):248-50. [CrossRef]

59. Ljungberg J, Hansson P, Adolfsson R, Nilsson L. The effect of language skills on dementia in a Swedish longitudinal cohort. Linguist Approaches Biling 2016; 6(1-2):190-204. [CrossRef]

60. Almkvist O. Neuropsychological Deficits in Vascular Dementia in Relation to Alzheimer's Disease: Reviewing Evidence for Functional Similarity or Divergence. Dement Geriatr Cogn Disord 1994;5(3-4): 203-9. [CrossRef] [PubMed]

61. Venkat P, Chopp M, Chen J. Models and mechanisms of vascular dementia. Exp Neurol 2015;272:97-108. [CrossRef] [PubMed]

62. Mathias J, Burke J. Cognitive functioning in Alzheimer's and vascular dementia: A meta-analysis. Neuropsychology 2009;23(4):411-23.

[CrossRef] [PubMed]

63. Shimokawa A, Yatomi N, Anamizu S, Torii S, Isono H, Sugai Y. Recognition of Facial Expressions and Emotional Situations in Patients with Dementia of the Alzheimer and Vascular Types. Dement Geriatr Cogn Disord 2003;15(3):163-68. [CrossRef] [PubMed]

64. Wechsler D. Wechsler Memory Scale-Revised Manual. San Antonio, TX: The Psychological Corporation; 1987.

65. Coughlan A, Hollows S. The adult memory and information processing battery (AMIPB). Leeds, UK: St James University Hospital; 1985.

66. Babcock H, Levy L. (1942). The measurement of Efficiency of Mental Functioning (Revised Examination): Test and Manual of Directions. Chicago, IL: $\mathrm{CH}$ Stoelting; 1940.

67. Zhou F, Chen D, Chen G, Liao P, Li R, Nong Q et al. Gene Set Index Based on Different Modules May Help Differentiate the Mechanisms of Alzheimer's Disease and Vascular Dementia. Clin Interv Aging 2021; 16: 451-63. [CrossRef] [PubMed]

68. Roman G, Tatemichi T, Erkinjuntti T, Cummings J, Masdeu J, Garcia J et al. Vascular dementia: Diagnostic criteria for research studies: Report of the NINDS-AIREN International Workshop. Neurology 1993;43(2):250-250. [CrossRef] [PubMed]

69. World Health Organization (WHO). The ICD-10 Classification of Mental and Behavioural Disorders. World Health Organization, 1993. [CrossRef]

70. American Psychiatric Association. American Psychiatric Association Committee on Nomenclature and Statistics. Diagnostic and Statistical Manual of Mental Disorders (DSM-IV), Fourth Edition. $4^{\text {th }}$ ed. Washington DC; 1994.

71. Chui H, Victoroff J, Margolin D, Jagust W, Shankle R, Katzman R. Criteria for the diagnosis of ischemic vascular dementia proposed by the State of California Alzheimer's Disease Diagnostic and Treatment Centers. Neurology 1992;42(3):473-473. [CrossRef] [PubMed]

72. Hachinski V, Iliff L, Zilhka E, Du Boulay G, McAllister V, Marshall J et al. Cerebral Blood Flow in Dementia. Arch Neurolog 1975;32(9): 632-7. [CrossRef]

73. Jellinger $\mathrm{K}$. The enigma of vascular cognitive disorder and vascular dementia. Acta Neuropathol 2007; 113(4):349-88. [CrossRef] [PubMed]

74. Krein L, Jeon Y, Amberber A, Fethney J. The Assessment of Language and Communication in Dementia: 
A Synthesis of Evidence. Am J Geriatr Psychiatry 2019;27(4):363-77. [CrossRef] [PubMed]

75. Goodglass H, Kaplan E. Boston diagnostic aphasia examination booklet. Philadelphia: Lea \& Febiger; 1983.

76. Kertesz A. Western aphasia battery test manual. Psychological Corp; 1982.

77. Kaplan E, Goodglass H, Weintraub. The Boston naming test. Philadelphia: Lea \& Febiger; 1983.

78. Bayles K, Tomoeda C. Arizona battery for communication disorders of dementia. Canyonlands Publishing; 1993. [CrossRef]

79. De Renzi E, Vignolo L. The Token test: a sensitive test to detect receptive disturbances in aphasics. Brain. 1962;85(4): 665-78. [CrossRef] [PubMed]

80. Hachinski V, Einhäupl K, Ganten D, Alladi S, Brayne C, Stephan B et al. Special topic section: linkages among cerebrovascular, cardiovascular, and cognitive disorders: Preventing dementia by preventing stroke: The Berlin Manifesto. Int $J$ Stroke 2019; 174749301987191. [CrossRef] [PubMed]

81. Solomon A, Mangialasche F, Richard E, Andrieu S, Bennett $D$, Breteler $M$ et al. Advances in the prevention of Alzheimer's disease and dementia. J Intern Med 2014;275(3):229-50. [CrossRef] [PubMed]

82. Hachinski V. Dementia: new vistas and opportunities. Neurol Sci 2019;40(4):763-7. [CrossRef] [PubMed]

83. Patel B, Perera M, Pendleton J, Richman A, Majumdar B. Psychosocial interventions for dementia: from evidence to practice. Adv Psychiatr Treat 2014; 20(5): 340-9. [CrossRef]

84. Zlobin OO. Psychotherapeutic support for persons with vascular dementia suffering from non-cognitive psychopathological symptoms of non-psychotic level. J Educ Health Sport 2020;10(3):98-107. [CrossRef]
85. Clare L. Rehabilitation for people living with dementia: A practical framework of positive support. PLOS Medic 2017;14(3):e1002245. [CrossRef] [PubMed]

86. Woods $B$, Aguirre $E$, Spector $A E$, Orrell M. Cognitive stimulation to improve cognitive functioning in people with dementia. Cochrane Database Syst Rev 2012; (2):CD005562. [CrossRef] [PubMed]

87. Soedirman B, Laksmidewi A. Benefit of Cognitive Stimulation Therapy in a Patient with Vascular Dementia: A Case Report. Open Access Maced J Med Sci 2021; 9(C):10-4. [CrossRef]

88. Clare L, Woods RT, Moniz Cook ED, Orrell M, Spector A. Cognitive rehabilitation and cognitive training for early-stage Alzheimer's disease and vascular dementia. Cochrane Database Syst Rev 2003;(4): CD003260. [CrossRef] [PubMed]

89. Bahar-Fuchs A, Clare L, Woods B. Cognitive training and cognitive rehabilitation for mild to moderate Alzheimer's disease and vascular dementia. Cochrane Database Syst Rev 2013;2013(6):CD003260. [CrossRef] [PubMed]

90. Vuković M. Afaziologija. $4^{\text {th }}$ ed. Beograd: Udruženje logopeda Srbije; 2016.

91. Gallego D. Rehabilitation in vascular dementia: Rehabilitation of speech and language manifestations of cognitive impairment in vascular dementia using a spaced repetition based approach. J Alzheimers Dis Parkinsonism 2016;6:3 (Suppl.). [CrossRef]

92. Klimova B, Maresova P, Kuca K. Assistive technologies for managing language disorders in dementia. Neuropsychiatr Dis Treat 2016;12:533-40. [CrossRef] [PubMed]

93. Banovic S, Zunic L, Sinanovic O. Communication Difficulties as a Result of Dementia. Mater Socio Med 2018;30(2):221-4. [CrossRef] [PubMed] 


\title{
KOGNITIVNI I JEZIČKI DEFICITI U VASKULARNOJ DEMENCIJI
}

\author{
Slavica Vasilijević ${ }^{1}$, Mile Vuković2 ${ }^{2}$ Lana Jerkić3 \\ ${ }^{1}$ Dom zdravlja Novi Beograd, Beograd, Srbija \\ ${ }^{2}$ Univerzitet u Beogradu, Fakultet za specijalnu edukaciju i rehabilitaciju, Beograd, Srbija \\ ${ }^{3}$ Univerzitet u Beogradu, Fakultet za specijalnu edukaciju i rehabilitaciju, student doktorskih studija, Beograd, Srbija
}

Kontakt: Slavica Vasilijević

Radnička 43/3a, 11000 Beograd, Srbija

E-mail: slavica.vasilijevic10@gmail.com

Vaskularne demencije (VaD) predstavljaju progresivni pad kognitivnih funkcija u meri u kojoj ometaju obavljanje svakodnevnih aktivnosti. Iako one predstavljaju relativno čest oblik demencije, koje se po učestalosti nalaze odmah nakon Alchajmerove bolesti (AB), daleko je manji broj studija koje su usmerene na izučvanje kognitivnih i bihevioralnih promena koje uzrokuje VaD, u odnosu na one studije koje izučavaju AB. Klinička slika i tok bolesti različiti su između pojedinih tipova.

Usled heterogenosti ispoljavanja kognitivnih deficita kod $\mathrm{VaD}$, u literaturi se o ovim deficitima u najvećoj meri izveštava kroz studije slučajeva i to kod, uglavnom, osoba sa supkortikalnim lezijama. Smetnje se manifestuju na kognitivnom, motornom, bihevioralnom i funkcionalnom planu. Vaskularne demencije klinički se manifestuju poremećajima jezika, pamćenja, rasuđivanja i egzekutivnih funkcija. Međutim, mogu se pojaviti i vizuospacijalni deficiti, poremećaji pažnje, praksije, rasuđivanja i drugi poremećaji. Kada se dogodi infarkt na nivou velikih krvnih sudova, uglavnom se manifestuju smetnje jezičkih i vizuospacijalnih sposobnosti, afazija, apraksija, smetnje pamćenja i amnezija. Nakon infarkta na nivou malih krvnih sudova, ispoljavaju se poremećaji egzekutivnih funkcija, pažnje, planiranja, izraženiji su neuropsihijatrijski simptomi i javljaju se drugi poremećaji.

Patofiziologija simptoma kognitivnog oštećenja usled $\mathrm{VaD}$ još uvek nije dovoljno poznata. Smatra se da tome doprinosi i pojava jezičkih poremećaja, manifestovanih kao afazije, što otežava procenu pamćenja i drugih kognitivnih funkcija. Važne segmente dijagnostike VaD predstavljaju neurološka i neuropsihološka procena, dok se tretman bazira na medikametnoj i govorno-jezičkoj terapiji, kao i na psihosocijalnoj podršci.

Acta Medica Medianae 2021;60(3):80-89.

Ključne reči: vaskularne demencije, kognitivni deficiti, jezički poremećaji, neuropsihološka procena, govorno-jezička terapija 